\title{
Impact of potassium levels and application timing on dry matter partitioning of wheat crop in Peshawar valley
}

\author{
Manzoor $^{1 *}$, Amir Sohail ${ }^{2}$, Shahzad Ali ${ }^{1}$, Muhammad Owais Khan ${ }^{3}$, \\ Shazma Anwar ${ }^{1}$, Haq Nawaz ${ }^{1}$, Farhan Ahmad ${ }^{1}$, Junaid Ahmad ${ }^{1}$, \\ Muhammad Waseem Abbas ${ }^{1}$ and Muhammad Kefayatullah ${ }^{4}$ \\ 1. Department of Agronomy, The University of Agriculture, Peshawar, Khyber Pakhtunkhwa-Pakistan \\ 2. Department of Plant Breeding and Genetics, The University of Agriculture, Peshawar, Khyber Pakhtunkhwa- \\ Pakistan \\ 3. Department of Soil and Environmental Sciences, The University of Agriculture, Peshawar, Khyber \\ Pakhtunkhwa-Pakistan \\ 4. Department of Food Science and Technology, The University of Agriculture, Peshawar, Khyber \\ Pakhtunkhwa-Pakistan \\ *Corresponding author's email: manzoor375351@gmail.com \\ Citation
}

Manzoor, Amir Sohail, Shahzad Ali, Muhammad Owais Khan, Shazma Anwar, Haq Nawaz, Farhan Ahmad, Junaid Ahmad, Muhammad Waseem Abbas and Muhammad Kefayatullah. Impact of potassium levels and application timing on dry matter partitioning of wheat crop in Peshawar valley. Pure and Applied Biology. Vol. 8, Issue 1, pp9-15. http://dx.doi.org/10.19045/bspab.2018.700158

\begin{tabular}{|c|c|c|c|}
\hline Received: 07/07/2018 & Revised: 25/09/2018 & Accepted: 28/09/2018 & Online First: 04/10/2018 \\
\hline
\end{tabular}

\section{Abstract}

A field experiment was conducted at Agronomy research farm, KPK, The University of Agriculture Peshawar during season 2016-17. The experiment was carried out in RCBD having 4 replications. The treatment consists of potassium levels $\left(0,60,90\right.$ and $\left.120 \mathrm{~kg} \mathrm{ha}^{-1}\right)$ and application time (full and split application). Wheat variety Pirsabak-2013 was sown at the rate of $120 \mathrm{~kg} \mathrm{ha}^{-1}$ in rows $3 \mathrm{~m}$ long and 30 $\mathrm{cm}$ apart. The results showed significant effect $(\mathrm{p} \leq 0.05)$ of potassium levels on dry matter partitioning in different parts of wheat. Maximum dry matter partitioning in Leaf $\left(116.28\right.$ and $\left.156.51 \mathrm{gm}^{-2}\right)$, Stem $\left(227.85\right.$ and $\left.386.53 \mathrm{gm}^{-2}\right)$, Spike $\left(22.95\right.$ and $\left.214.05 \mathrm{gm}^{-2}\right)$, and Total dry matter $\left(407.31\right.$ and $\left.757.09 \mathrm{gm}^{-2}\right)$ at booting and anthesis stage, and Maximum dry matter partitioning in Leaf $\left(345 \mathrm{gm}^{-2}\right)$, Stem $\left(420.1 \mathrm{gm}^{-}\right.$ ${ }^{2}$ ), Spike straw $\left(365.46 \mathrm{gm}^{-2}\right)$, Grain $\left(515.5 \mathrm{gm}^{-2}\right)$ and Total dry matter $\left(1646.1 \mathrm{gm}^{-2}\right)$ at physiological maturity stage were recorded with potassium application at a rate of $90 \mathrm{~kg} \mathrm{ha}^{-1}$. The interaction of potassium levels and application time had also a significant effect on total dry matter partitioning. Potassium $90 \mathrm{~kg} \mathrm{ha}^{-1}$ with full dose application at booting stage produced maximum dry matter partitioning $\left(413.18 \mathrm{gm}^{-2}\right)$ and at anthesis and physiological maturity stage maximum dry matter partitioning (763.45 and $1648.3 \mathrm{gm}^{-2}$ ) were recorded with potassium $90 \mathrm{~kg} \mathrm{ha}^{-1}$ and split dose application(half at sowing + half at tillering). Based on the results, among potassium levels, $90 \mathrm{~kg} \mathrm{ha}^{-1}$ produced more dry matter partitioning as compare to other levels of potassium. So potassium level 90 $\mathrm{kg} \mathrm{ha}^{-1}$ is recommended for high dry matter partitioning in different parts of wheat in Peshawar valley. Keywords: Application time; Dry matter partitioning; Peshawar valley; Potassium levels

\section{Introduction}

Wheat (Triticum aestivum L.) is a vital cereal crop belong with the family of gramineae and it is grown in winter season and harvested in summer months so it is consider as a winter cereal. Wheat crop is $\mathrm{C} 3$ in nature and as a staple food not only in Pakistan but feed one fifth of the world. 
Pakistan is one of the leading country in production of wheat because wheat occupy largest area under single crop that is 9180 thousands hectares and produce 25.478 million tons (Pakistan bureau of statistics, 2015 ).Our country produce $3.16 \%$ of the world production of wheat which contributes $2.1 \%$ to Gross domestic production and added $10 \%$ value to agriculture. However to obtain the potential yield of wheat fertilizer is an important and expensive input such as consequence of it is highlighted in green revolution. So the balance use of fertilizer can increase yield from $30-47 \%$ [1] and it is estimated that one $\mathrm{kg}$ of fertilizer nutrient produce about $8 \mathrm{~kg}$ of cereal that is wheat [2].

In terms of $\mathrm{kg} \mathrm{ha}^{-1}$ wheat and other cereal crops require about the same amount of $\mathrm{K}$ as $\mathrm{N}$ and in some instances the need for $\mathrm{K}$ may exceed that of N [3]. Soil available K level, amount of applied $\mathrm{K}$ fertilizer, soil fertility level and crop varieties influence total $\mathrm{K}$ uptake. Generally the final quantity of $\mathrm{K}$ in cereals is $5 \mathrm{~kg} \mathrm{ton}^{-1}$ grain and 10 to $20 \mathrm{~kg} \mathrm{ton}^{-1}$ straw for a wide range of conditions in the absence of deficiencies or excesses [4]. Among macro nutrients potassium is one of the desirable nutrient require in large amount for crops after nitrogen and phosphorous [5]. The $\mathrm{K}$ requirement for optimal plant growth is 2 to $5 \%$ of the plant dry weight [6]. However, this requirement is often not met due to adverse soil and plant factors, and deficiencies occur with resulting yield reductions. Furthermore, the concentration of $\mathrm{K}$ available to the plant is often influenced by the availability abundance of other essential elements.

It play a key role in growth and sustainable crop production [7] Cereals can uptake 2$3 \%$ more potassium then legume [8]. The role of $(\mathrm{K})$ is well documented in photosynthesis, carbohydrates, starch formation, plant ability to resist insect pest and develop tolerance in drought condition. It also sustains turger of cell which helps extension, opening and closing of stomata and osmoregulation system of plant cell. It can activate more than 90 enzymes which is important for photosynthesis [9]. Potassium fertilization has a great effect on growth, expansion and yield of wheat [10] Wheat crop yield and quality of products can improve with (K) application [9].

Photosynthetic source material with a reduction in the photosynthetic rate per unit leaf area, and the result is an overall reduction in the amount of photosynthetic assimilates available for growth. [11] Reported that the production of less photosynthetic Potassium deficiency can lead to a reduction in both the number of leaves produced and the size of individual leaves. Coupling this reduced amount of assimilates and reduced assimilate transport out of the leaves to the developing fruit greatly contributes to the negative consequences that deficiencies of potassium have on yield and quality production.

The deficiency of $\mathrm{K}$ leads to decrease the amount of protein and nitrogen uptake in the form of nitrate [12] so addition of potassium to wheat crops increase metabolism, quality, because it helps in grain filling, kernels weight and strength of straw [13] and translocation of photosynthesis.

Keeping all of the above observation in view an experiment was conducted to evaluate the optimum potassium level among three levels and application timing of potassium and interaction between potassium levels and application timing on dry matter portioning of wheat crop.

\section{Materials and methods}

A field experiment entitled "Effect of potassium levels and its application timing on dry matter partitioning of wheat" was conducted at Agronomy farm, Khyber Pakhtunkhwa (KPK) The University of Agriculture Peshawar during Rabi season 2016-2017. The experiment was carried out in Randomized Complete Block Design (RCBD) having four replications. The treatment consists of potassium levels $(0$, 60,90 and $120 \mathrm{~kg} \mathrm{ha}^{-1}$ ) and application time (full and split application). Plot size was 
kept $3 \mathrm{~m}$ x $2.5 \mathrm{~m}$. Wheat variety Pirsabak2013 was sown at the rate of $120 \mathrm{~kg} \mathrm{ha}^{-1}$ in rows $3 \mathrm{~m}$ long and $30 \mathrm{~cm}$ apart. Each plot was consisted of eight rows. Sulphate of potash (SOP) was used as a source of potassium. It was applied to the field before sowing at two different timings full dose at sowing and in split half each at sowing and tillering stage. All other agronomic practices such as hoeing, weeding and irrigation etc were carried out uniformly throughout the experiment. Data was recorded on dry matter partitioning in Leaf $\left(\mathrm{gm}^{-2}\right)$, Stem $\left(\mathrm{gm}^{-2}\right)$, Spike $\left(\mathrm{gm}^{-2}\right)$, Grains in Spike $\left(\mathrm{gm}^{-2}\right)$, Spike straw $\left(\mathrm{gm}^{-2}\right)$ and total dry matter $\left(\mathrm{gm}^{-2}\right)$ parameters at booting, anthesis and physiological maturity stage. Dry matter partitioning was calculated by taking two random samples of $0.5 \mathrm{~m}$ long rows at booting, anthesis and physiological maturity stage in each subplot. The material was divided into leaf, stem and spikes, and then spike in grains and spike straw at anthesis and physiological maturity stage, kept in paper bags and sun dried up to constant weight. Each sample was weighted by electronic balance and leaf, stem, spike, grains and spike straw dry weight was calculated.

\section{Dry matter partitioning $\left(\mathrm{gm}^{-2}\right)=\frac{\text { Sun dried sample constant weight }(\mathrm{g})}{\text { Row-Row distance } \mathrm{x} \text { Row length } \mathrm{x} \text { No. of Rows }} \times 1 \mathrm{~m}$}

\section{Statistical analysis}

Analysis of variance procedure was followed for statistical analysis of recorded data according to the design used. Means were compared using least significant difference (LSD) test at $\mathrm{P} \leq 0.05$ upon significant F-test [13].

\section{Results and discussion}

\section{Leaf dry matter $\left(\mathrm{gm}^{-2}\right)$}

Statistical analysis of the data showed that potassium levels significantly affected leaf dry matter at booting stage (Table 1). Maximum leaf dry matter (116.28) $\mathrm{gm}^{-2}$ was produced with application of potassium at $90 \mathrm{~kg} \mathrm{ha}^{-1}$ and minimum leaf dry matter (69.6) $\mathrm{gm}^{2}$ was produced with potassium 60 $\mathrm{kg} \mathrm{ha}^{-1}$. Similar result was revealed by [14] that leaf dry matter was higher at $90 \mathrm{~kg} \mathrm{ha}^{-}$ ${ }^{1}$ of $\mathrm{K}$ application. But in contrast analysis also showed that both the application timings and interaction were nonsignificant effect on leaf dry matter at booting stage. Means of both application timing was recorded same effect and similar result is revealed by [15] reported that there is no significant effect of potassium timing of application on dry matter. ". Potassium application significantly increased leaf dry matter at booting stages as compared to control plots.
Leaf dry matter at anthesis and physiological maturity stages was significantly affected by potassium levels, analysis showed that maximum leaf dry matter (156.51 and 345.03) $\mathrm{gm}^{-2}$ was obtained with the application of potassium at $90 \mathrm{kgha}^{-1}$ and minimum leaf dry matter (135.3 and 299.3) $\mathrm{gm}^{-2}$ was recorded with potassium $60 \mathrm{~kg} \mathrm{ha}^{-1}$. Similar result was also found with [16] leaf dry matter partitioning increases with $\mathrm{K}$ application at the rate of $90 \mathrm{~kg} \mathrm{ha}^{-1}$ at anthesis and physiological maturity stages. Analysis also showed that both the application timings of $\mathrm{K}$ was non-significantly affected leaf dry matter at anthesis and physiological maturity stages, also the interaction of potassium levels and timings was found non-significant. The contrast analysis between control and potassium application show that potassium application significantly increased leaf dry matter at anthesis and physiological maturity stages as compare to control plots.

\section{Stem dry matter $\left(\mathrm{gm}^{-2}\right)$}

Analysis of the data in (Table 1) indicate that impacts of potassium levels significantly affected stem dry matter $\mathrm{gm}^{-2}$ at booting, anthesis and physiological maturity stages and showed that both application timings have no significant 
effect on stem dry matter at booting anthesis and physiological maturity stages. Whiles the interaction of application timing and $\mathrm{K}$ levels were also found nonsignificant. Statistical analysis shows that mean maximum stem dry matter (227.9, $386.5,420.1) \mathrm{gm}^{-2}$ at booting, anthesis and physiological maturity stages were produced at potassium application of $90 \mathrm{~kg}$ $\mathrm{ha}^{-1}$ and minimum stem dry matter (192.24, $230.01,238.5) \mathrm{gm}^{-2}$ was obtained in plots treated with potassium $60 \mathrm{~kg} \mathrm{ha}^{-1}$. Similar result was also noted by [17-19] that with increasing of potassium rate can significantly increase the stem dry matter at booting, anthesis and physiological maturity stages and generally, application of potassium increases of nitrogen metabolism, carbohydrates metabolism, enzymes activity, tissues growth, protein synthesis, crop quality and resistance of crop against disease and pests attack but the result was in contrast with application timing. Analysis also showed that Potassium application significantly increased stem dry matter at booting, anthesis and physiological maturity stages as compared to control plots.

\section{Spike dry matter $\left(\mathrm{gm}^{-2}\right)$}

Analysis of the data recorded on spike dry matter in (Table 1) showed that potassium levels had significantly affected spike dry matter at booting stage. Analysis also showed that maximum spike dry matter (22.95) $\mathrm{gm}^{-2}$ was obtained at potassium 90 $\mathrm{kg} \mathrm{ha}{ }^{-1}$ and minimum spike dry matter (15.03) $\mathrm{gm}^{-2}$ was recorded with potassium $60 \mathrm{~kg} \mathrm{ha}^{-1}$. While both of application timings had non-significant effect on spike dry matter at booting stage. The interaction of $\mathrm{K}$ levels and timings were also found non-significant. [17] Recorded that with increasing of potassium rate can significantly increase the spike dry matter at booting and it is due to the fact that potassium increases nitrogen assimilation. The contrast analysis show that potassium application significantly increased spike dry matter at booting stage as compare to control plots.

Statistical analysis showed that potassium levels significantly affected spike dry matter at anthesis and physiological maturity stages. Maximum spike dry matter (214.05 and 365.46) $\mathrm{gm}^{-2}$ were recorded at potassium level $90 \mathrm{kgha}^{-1}$ while the minimum spike dry matter (139.21 and 221.88) $\mathrm{gm}^{-2}$ were recorded in plots treated with potassium $60 \mathrm{~kg} \mathrm{ha}^{-1}$. Analysis also showed that both of the application timings had non-significant effect on spike dry matter at anthesis and physiological maturity stages. While the interaction of potassium levels and timing was also found non-significant. But in contrast [20] conducted a field experiment to check the potassium effect on yield of wheat and rice crop recorded that spike dry matter was more with application of potassium at $60 \mathrm{~kg}$ $\mathrm{ha}^{-1}$. Potassium application significantly increased spike dry matter at anthesis and physiological maturity stages as compared to control plots.

\section{Total dry matter $\left(\mathrm{gm}^{-2}\right)$}

Analysis of the data recorded on total dry matter in (Table 1) showed that potassium levels had significantly affected total dry matter at booting stage. Analysis also showed that maximum total dry matter (407.31) $\mathrm{gm}^{-2}$ was obtained at potassium 90 $\mathrm{kg} \mathrm{ha}^{-1}$ and minimum total dry matter (342.56) $\mathrm{gm}^{-2}$ was recorded in plots treated with potassium $60 \mathrm{~kg} \mathrm{ha}{ }^{-1}$. While the application timings had non-significant effect on total dry matter at booting stage. The interaction of $\mathrm{K}$ levels and timings were found significant. More total dry matter (413.18) $\mathrm{gm}^{-2}$ was observed in plots treated with potassium $90 \mathrm{~kg} \mathrm{ha}^{-1}$ with full dose application, while minimum total dry matter (330.28) $\mathrm{gm}^{-2}$ at booting stage was observed in plots treated with potassium 60 $\mathrm{kg} \mathrm{ha}^{-1}$ with full dose application. [17] Recorded that with increasing of potassium rate can significantly increase the total dry matter at booting and it is because of that potassium increases nitrogen assimilation. 
Pure Appl. Biol., 8(1): 9-15, March, 2019

http://dx.doi.org/10.19045/bspab.2018.700158

Table 1. Effect of potassium levels and application timing on dry matter partitioning of wheat

\begin{tabular}{|c|c|c|c|c|c|c|c|c|c|c|c|c|c|c|}
\hline & \multirow[t]{2}{*}{ Treatments } & \multicolumn{4}{|c|}{$\begin{array}{l}\text { Dry matter at booting stage } \\
\qquad\left(\mathrm{g} / \mathrm{m}^{2}\right)\end{array}$} & \multicolumn{4}{|c|}{$\begin{array}{l}\text { Dry matter at anthesis g stage } \\
\qquad\left(\mathrm{g} / \mathrm{m}^{2}\right)\end{array}$} & \multicolumn{5}{|c|}{ Dry matter at physiological maturity stage $\left(\mathbf{g} / \mathbf{m}^{2}\right)$} \\
\hline & & Leaf & Stem & Spike & Total & Leaf & Stem & Spike & Total & Leaf & Stem & Grain & Spike straw & Total \\
\hline \multirow{3}{*}{$\begin{array}{c}\text { Time of } \\
\text { application }\end{array}$} & T1 & 92.3 & 212.03 & 19.58 & 380.15 & 148.55 & 281.92 & 172.17 & 602.63 & 319.55 & 327.10 & 457.04 & 302.83 & 1406.5 \\
\hline & $\mathbf{T 2}$ & 97.56 & 216.63 & 19.75 & 384.35 & 147.98 & 307.95 & 183.47 & 639.39 & 321.26 & 322.38 & 456.57 & 309.82 & 1410.0 \\
\hline & LSD(0.05) & NS & NS & NS & NS & NS & NS & NS & NS & NS & NS & NS & NS & NS \\
\hline \multirow{3}{*}{$\begin{array}{l}\text { Potassium } \\
\text { (K) levels }\end{array}$} & K1 & $69.6 \mathrm{c}$ & $192.24 \mathrm{~b}$ & $15.03 \mathrm{~b}$ & $342.56 \mathrm{~b}$ & $135.3 \mathrm{~b}$ & $230.01 \mathrm{c}$ & $139.21 \mathrm{c}$ & $504.53 \mathrm{c}$ & $299.3 \mathrm{~b}$ & $238.5 \mathrm{c}$ & $388.8 \mathrm{c}$ & $221.88 \mathrm{c}$ & $1148.5 \mathrm{c}$ \\
\hline & K2 & $116.28 \mathrm{a}$ & $227.85 \mathrm{a}$ & $22.95 \mathrm{a}$ & $407.31 \mathrm{a}$ & $156.51 \mathrm{a}$ & $386.53 \mathrm{a}$ & $214.05 \mathrm{a}$ & $757.09 \mathrm{a}$ & $345.0 \mathrm{a}$ & $420.1 \mathrm{a}$ & $515.5 \mathrm{a}$ & $365.46 \mathrm{a}$ & $1646.1 \mathrm{a}$ \\
\hline & K3 & $98.9 \mathrm{~b}$ & $222.89 \mathrm{a}$ & $21.01 \mathrm{a}$ & $396.86 \mathrm{a}$ & $152.98 \mathrm{a}$ & $268.26 \mathrm{~b}$ & $180.19 \mathrm{~b}$ & $601.4 \mathrm{~b}$ & $316.9 \mathrm{~b}$ & $315.6 \mathrm{~b}$ & $466.1 \mathrm{~b}$ & $331.63 \mathrm{~b}$ & $1430.2 b$ \\
\hline & $\operatorname{LSD}(0.05)$ & 3.74 & 8.79 & 0.68 & 8.31 & 4.79 & 11.83 & 8.62 & 21.37 & 10.58 & 6.82 & 14.47 & 11.83 & 26.60 \\
\hline \multirow{7}{*}{$\begin{array}{c}\text { Time of } \\
\text { application } \times \\
\text { Potassium }(K) \\
\text { levels }\end{array}$} & K1T1 & 63.8 & 182.4 & 14.93 & 330.23 & 132.9 & 215.03 & 127.63 & 475.55 & 298.45 & 245.30 & 390.50 & 218.50 & 1144.2 \\
\hline & K1T2 & 75.4 & 202.08 & 15.13 & 354.9 & 137.7 & 245.00 & 150.80 & 533.50 & 300.15 & 231.70 & 387.10 & 225.25 & 1152.75 \\
\hline & K2T1 & 111.68 & 231.58 & 22.98 & 413.18 & 158.62 & 384.80 & 207.30 & 750.73 & 335.68 & 422.25 & 522.50 & 363.50 & 1643.9 \\
\hline & K2T2 & 120.9 & 224.13 & 22.93 & 401.45 & 154.4 & 388.25 & 220.80 & 763.45 & 354.38 & 418.00 & 508.50 & 367.43 & 1648.3 \\
\hline & K3T1 & 101.42 & 222.1 & 20.83 & 397.05 & 154.12 & 245.93 & 181.58 & 581.63 & 324.53 & 313.75 & 458.13 & 326.48 & 1422.9 \\
\hline & K3T2 & 96.38 & 223.68 & 21.2 & 396.7 & 151.82 & 290.60 & 178.80 & 621.23 & 309.25 & 317.45 & 474.10 & 336.78 & 1437.6 \\
\hline & $\operatorname{LSD}(0.05)$ & NS & NS & NS & 17.76 & NS & NS & NS & 44.32 & NS & NS & NS & NS & 84.49 \\
\hline \multirow{3}{*}{ Control vs rest } & Control & $59.7 \mathrm{~b}$ & $113.6 \mathrm{~b}$ & $8.53 \mathrm{~b}$ & $199.9 \mathrm{~b}$ & $77.78 \mathrm{~b}$ & $194.03 \mathrm{~b}$ & $119.4 \mathrm{~b}$ & $391.2 \mathrm{~b}$ & $257.7 \mathrm{~b}$ & $202.7 \mathrm{~b}$ & $362.4 \mathrm{~b}$ & $176.75 \mathrm{~b}$ & $999.53 b$ \\
\hline & Rest & $94.93 \mathrm{a}$ & $214.33 \mathrm{a}$ & $19.66 \mathrm{a}$ & $382.25 \mathrm{a}$ & $148.26 \mathrm{a}$ & $294.93 \mathrm{a}$ & $177.82 \mathrm{a}$ & $621.01 \mathrm{a}$ & $320.4 \mathrm{a}$ & $324.7 \mathrm{a}$ & $456.8 \mathrm{a}$ & $306.32 \mathrm{a}$ & $1408.3 \mathrm{a}$ \\
\hline & $\operatorname{LSD}(0.05)$ & 11.17 & 20.51 & 1.60 & 20.48 & 8.73 & 30.23 & 20.11 & 51.71 & 39.93 & 35.42 & 43.56 & 35.62 & 100.93 \\
\hline
\end{tabular}

Note: T1- Application time (Full at sowing); T2-Application time (Half at sowing + half at tillering); K1- Potassium level (60 kg/ha); K2- Potassium level (90 kg/ha); K3-

Potassium level (120 kg/ha); NS-non-significant; LSD-least significant difference 
Analysis of data indicated that Potassium application significantly increased total dry matter at booting stage as compared to control plots. Total dry matter at anthesis and physiological maturity stages were significantly affected potassium levels. While potassium application timing had a non-significant effect on total dry matter at anthesis and physiological maturity stages. Maximum total dry matter $(757.09,1646.1)$ $\mathrm{gm}^{-2}$ at anthesis and physiological maturity stages were recorded at potassium level 90 $\mathrm{kg} \mathrm{ha}^{-1}$ while minimum total dry matter $(504.53,1148.5) \mathrm{gm}^{-2}$ at anthesis and physiological maturity stages were recorded in plots treated with potassium 60 $\mathrm{kg} \mathrm{ha}^{-1}$. Similar result was obtained by [21] noted a significant increase in total dry matter with $\mathrm{K}$ application at the rate of 90 $\mathrm{kg} \mathrm{ha}^{-1}$. In contrast [17] revealed total dry matter was effected with potassium application at 160 may be because of the probable reason for increase in total dry matter of maize with $\mathrm{K}$ application probably might be due to the increased rate of $\mathrm{CO}_{2}$ assimilation, stabilized the stomata regulation, improved stomata closure and enzyme activity as a result of which more carbohydrates might have produced and hence increased total dry matter at this stage. The interaction of potassium levels and timings were found significant. Plots treated with potassium $90 \mathrm{~kg} \mathrm{ha}^{-1}$ and split dose application(half at sowing + half at tillering) produced maximum total dry matter $(763.45,1648.3) \mathrm{gm}^{-2}$ at anthesis and physiological maturity stages, while in plots treated with potassium $60 \mathrm{~kg} \mathrm{ha}^{-1}$ with full dose application produced minimum total dry matter $(475.55,144.2) \mathrm{gm}^{-2}$ at anthesis and physiological maturity stages. The contrast analysis show that potassium application significantly increased total dry matter at anthesis and physiological maturity stages as compare to control plots.

Grain dry matter $\left(\mathrm{gm}^{-2}\right)$ at physiological maturity stage

Means values of Grain dry matter showed in (Table 1) indicate that grain dry matter of wheat was significantly affected by different potassium levels, while potassium application timing had a non-significant effect on grain dry matter. The interaction was also found non-significant. Means values of potassium levels show that plots treated with potassium $90 \mathrm{~kg} \mathrm{ha}^{-1}$ produced maximum grain dry matter (515.5) $\mathrm{gm}^{-2}$ while minimum grain dry matter (388.8) $\mathrm{gm}^{-2}$ was observed in plots treated with potassium $60 \mathrm{~kg} \mathrm{ha}^{-1}$. The contrast analysis show that potassium application significantly increased grain dry matter as compare to control plots.

\section{Conclusion}

Potassium application at the rate of $90 \mathrm{~kg}$ $\mathrm{ha}^{-1}$ produced maximum Dry matter portioning in Leaf, Stem, Spike, Grains and Spike straw of wheat crop at booting, anthesis and physiological maturity stages. Application timing of potassium application have a non-significant effect on dry matter portioning. Total dry matter portioning was more when wheat crop treated with potassium $90 \mathrm{~kg} \mathrm{ha}^{-1}$ with full dose application at booting stage, while at anthesis and physiological maturity stages higher total dry matter portioning was recorded in plots treated with potassium 90 $\mathrm{kg} \mathrm{ha}^{-1}$ with split dose application(half at sowing + half at tillering).

\section{Authors' contributions}

Conceived and designed the experiments: A Sohail \& S Ali, Performed the experiments: Manzoor, Analyzed the data: Manzoor, Contributed reagents/ materials/ analysis tools: S Anwar, MO Khan, $\mathrm{H}$ Nawaz, F Ahmad, J Ahmad, MW Abbas \& M Kefayatullah, Wrote the paper: Manzoor.

\section{References}

1. Tahir MA, Tanveer A, Ali H, Ashraf M \& Wasaya A (2008). Growth and yield response of two wheat (Triticum aestivum L.) varieties to different potassium levels. Pak J life Soc 6(2): 92-95.

2. Pakistan Bureau of Statistics Source (2015).

3. Kemmler G (1983). Modern Aspects of Wheat Manuring. IPI-Bulletin 1. 
International Potash Institute, Basel, Switzerland.

4. Mengel K (1982). Factors and processes affecting potassium requirements of crops. Subject 16, 90th suite. Potash Review (9): 1-12.

5. Brady NC (1990). The nature and properties of soils. $10^{\text {th }}$ ed. Macmillan publishing Co., New York, USA: 8790.

6. Marschner H (1995). Mineral Nutrition of Higher Plants. Academic Press Inc London. pp 651.

7. Alderfasi AA \& Refay YA (2010). Integrated use of potassium fertilizer and water schedule on growth and yield of two wheat genotypes under arid environment in Saudi Arabia 1- Effect on growth characteristics AmericanEurasians. J Agric \& Environ Sci 9(3): 339-247.

8. Bajwa MI (1994). Soil potassium status, potash fertilizer usage and recommendation in Pakistan. International Potash Institute, Berne, Switzerland, Potash Review No 3.

9. Mengel K \& Kirby EA (1987). Principles of Plant Nutrition, $4^{\text {th }}$ ed. International Potash Institute, Horgen, Switzerland.

10. Saifullah AM, Ranjha M, Yaseen M \& Akhtar ME (2002). Response of wheat to potassium fertilization under field conditions. Pak J Agri Sci 39(4): 91-93.

11. Pettigrew WT (2008). Potassium influences on yield and quality production for Maize, wheat, soybean and cotton. Physiol Planetarium (133): 670-68.

12. Rashid H, Ranjha HAM, Mehdi SM \& Safiullah (2001). Relative Efficiency of Murate and Sulphate of potash for wheat. International J of Agric and Bio (3): 403-405.
13. Ashley MK, Grant M \& Grabov A (2011). Biological and mineral nitrogen supply impact on salinity response of faba bean (Vica faba) in Abdurrahman M Almandine. Euro J of Sci Res 49(2): 189-199.

14. Mengel K, Secer M \& Koch K (1981). Potassium effect on protein formation and amino acid turnover in developing wheat grain. Agron J 73: 74-78.

15. Nasir A, Sarfraz M, Farooq U, Arfanul-Haq M, Mushtaq MZ \& Ali MA (2015). Effect of potassium and its time of application on yield and quality of tomato. Inter J of Sci and Res Public 5(9): 23-31

16. Baque MB, Karim MA, Hamid A \& Tesushi H (2006). Effect of fertilizer potassium on growth, yield and nutrient uptake of wheat under water stress condition. South Pacific Stud 27(1): 2535.

17. Tabatabaei, Ali S, Shakeri SS \& Mirjalili MR (2014). Effect of different levels of potassium Sulphate on yield, yield components and protein content of wheat cultivars. Appl Math in Engi, Manage and Technol 2(3): 119-123.

18. Kafkafi U, Bar-Yosef BA \& Hadas A (1978). Fertilization decision model. Soil Sci 125: 261-268.

19. Amanullah, Asif M, Shah Z \& Hassan $M$ (2007). Potassium effects on the yield and yield components of maize in Northwest Pakistan. Ann Agrarian Sci 5(4): 13-17.

20. Khan R, Gurmani AH \& Zia MS (2007). Effect of potassium application on crop yields under wheat- rice system. Sarhad J of Agri 23: 277-279.

21. Chaudhry A \& Malik JK (2000). Determination of optimum level of potash and its effect on yield and quality of maize. Pak J Bio Sci 3(12): 75-80. 